\title{
The charming physician (El médico encantador): neurological conditions in a short story by Silvina Ocampo
}

\author{
O médico encantador (El médico encantador): doenças neurológicas \\ em um conto de Silvina Ocampo
}

Guillermo Delgado-García ${ }^{1}$ Carolina Rodriguez-Návarez ${ }^{2,3}$, Bruno Estañol4

\begin{abstract}
The Argentinian author Silvina Ocampo (1903-1993) left us a vast body of works which are considered outstanding in many ways. In 1960, she published a short story, entitled "El médico encantador" (The Charming Physician), in the renowned literary magazine Sur. The central character of this piece is a family doctor named Albino Morgan, who had a secret truth: in any house he visited, all variety of disease also entered. He brought with him the viruses he disseminated. The narrator of this short story-one of his patients-describes four of Morgan's diseases. These imaginary neurological conditions allowed Ocampo to explore improbable situations in everyday life.
\end{abstract}

Keywords: neurology; medicine in literature; medicine in art; agnosia; sleep initiation and maintenance disorders

RESUMO

A autora argentina Silvina Ocampo (1903-1993) deixou-nos uma vasta obra que é considerada excelente de várias maneiras. Em 1960, publicou um conto, intitulado "El médico encantador" (O médico encantador), na famosa revista literária Sur. O personagem principal desta obra é um médico de família chamado Albino Morgan que possuía uma verdade secreta: em qualquer casa que ele visitava, também entrava toda a diversidade de doenças. O narrador deste conto -um dos seus pacientes- descreve quatro das doenças de Morgan. Estas condições neurológicas imaginárias permitiu a Ocampo explorar as situações improváveis da vida quotidiana.

Palabras-Clave: neurologia; medicina na literatura; medicina na arte; agnosia; distúrbios do início e da manutenção do sono

If a sufferer from tactile agnosia is given an object familiar to him in daily life, he can indicate that it feels cold and smooth and heavy, but not that it is a coin.

- Cassirer, The Philosophy of Symbolic Forms, vol. $3^{1}$.

The Argentinian author Silvina Ocampo (1903-1993) (Figure) was born in Buenos Aires. It was there where she devoted herself to writing. Victoria Ocampo, her elder sister, was the founder of the renowned literary magazine Sur. Jorge Luis Borges and Adolfo Bioy Casares collaborated frequently in this magazine. In 1940, Silvina Ocampo and the latter were married. Ocampo masterfully practiced prose, poetry and translation ${ }^{2}$.
Ocampo left us a vast body of works which are considered outstanding in many ways. Her literary quest was directed toward the act of finding meaning for that amorphous aspect of daily life that we often ignore. She shows us the marvelous and the terrible, not as part of the extraordinary incident, but rather of the Augustinian retirement of the very interiority ${ }^{3}$. In her youth, Ocampo studied painting in Paris with Giorgio de Chirico (1888-1978) ${ }^{2}$. The influence of this painter is patent in one of her poems entitled "Epístola a Giorgio de Chirico" (Epistle to Giorgio de Chirico), which was included years later in "Poemas de amor desesperado" (Poems of Desperate Love, 1949): "Lo que aún no pintó, para mí existe / con imágenes suyas en mis ojos" (What he had not yet painted, for me it

${ }^{1}$ Autonomous University of Nuevo León, University Hospital, Department of Internal Medicine, Monterrey, Mexico;

${ }^{2}$ Monterrey Institute of Technology and Higher Education, Prepa Tec Santa Catarina, Department of Spanish, Monterrey, Mexico;

${ }^{3}$ ALFA Foundation, Extracurricular Talent Center (II), Monterrey, Mexico;

${ }^{4}$ National Institute of Medical Sciences and Nutrition, Laboratory of Clinical Neurophysiology, Mexico City, Mexico.

Correspondence: Guillermo Delgado-García; Departamento de Medicina Interna, Hospital Universitario "Dr. José Eleuterio González"; Madero y Gonzalitos s/n, Col. Mitras Centro; C.P. 64460, Monterrey, Nuevo León, México; E-mail: grdelgadog@gmail.com

Conflict of interest: There is no conflict of interest to declare.

Received 09 November 2016; Received in final form 08 June 2017; Accepted 18 July 2017. 


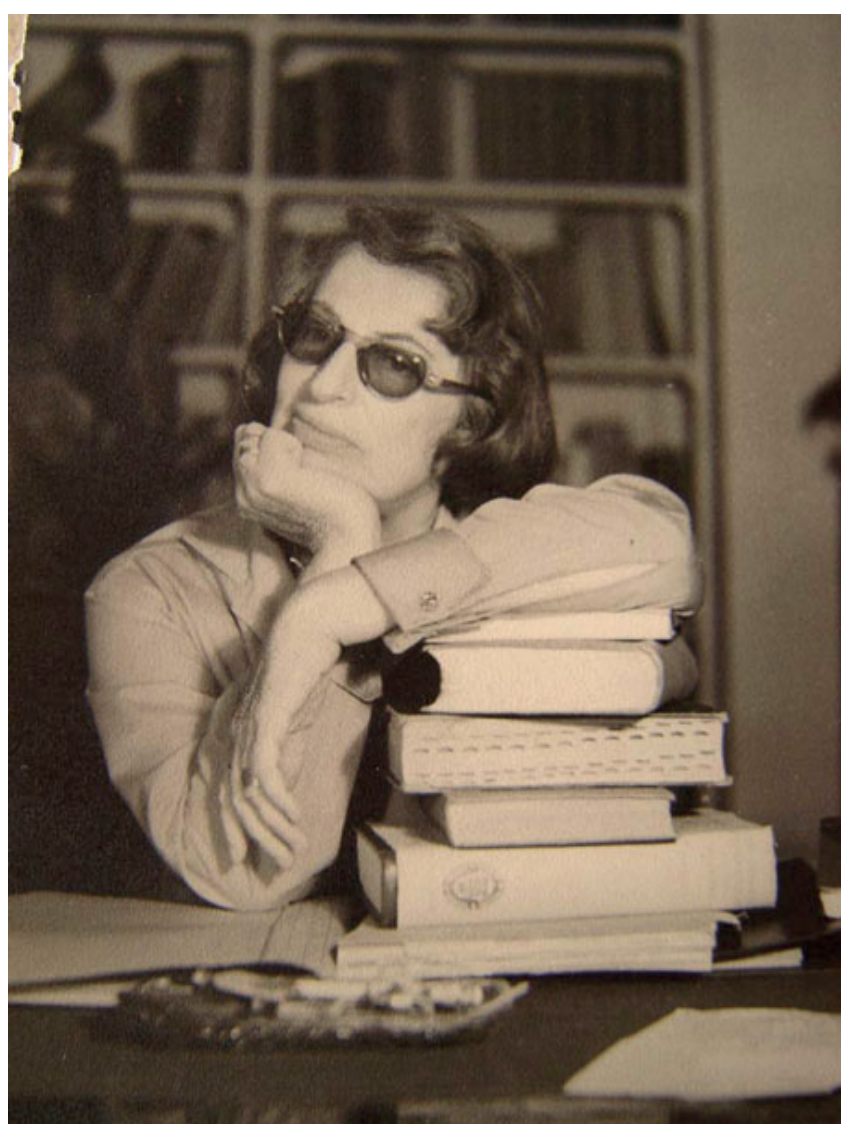

Figure. Silvina Ocampo (1903-1993) photographed by Adolfo Bioy Casares (1914-1999) in 1959, one year before the publication of "El médico encantador" (The Charming Physician) in the renowned literary magazine Sur.

exists / with images of him in my eyes) ${ }^{4}$. This poetic confession will facilitate the understanding of what follows.

In 1960, Ocampo published a short story, entitled "El médico encantador" (The Charming Physician), in Sur 5 . The central character of this piece is a family doctor named Albino Morgan. He was original or eccentric, and had the odd habit of telling the truth in jest. "Under his influence patients fall in love with their diseases." At a given point, he began to excessively vary his remedies, and started to introduce therapeutic innovations. Doctor Morgan had a secret truth: in any house he visited, all variety of disease also entered. "As soon as he pronounced some unintelligible words, the healthier patient developed fever or stomach upset." He brought with him the viruses he disseminated, which he cultivated in his own house, as told by one of his colleagues. It is unclear what he used as fomite: maybe an X-ray generator manometer, a thermometer, or candies. Our charming doctor also named the diseases he spread. This plot is a sample of Ocampos "strange taste for a certain kind of innocent and oblique cruelty", which had already been noted by Jorge Luis Borges ${ }^{6}$. This cruelty has been attributed "to the gap of incomprehension separating the child world from the adult" world ${ }^{7}$. The narrator of this short story-one of his pediatric patients-describes four of Morgan's diseases.
"Colmenares nocturnos" (nocturnal beehives): The presenting symptoms of this imaginary condition are mild headache and dizziness. The patient then begins to hear a buzzing "similar to that which surrounds and overflows a beehive on hot days". This buzz can be heard by others (i.e., objective tinnitus). Later in the course of this disease, in the dark, the patient thinks he sees, in shades of violent yellow, a perfectly-drawn honeycomb. This visual hallucination declines when the light is turn on. At the same time, he develops gustatory hallucinations (a taste of honey), which cause him polydipsia. Fever and nightmares begin afterwards. Honey is the common theme of all these nightmares.

"Cromosis tisular" (tissular chromosis): Etymologically, chromosis means color disease ( from the Greek $\chi \rho \tilde{\omega} \mu \alpha$, 'color', and the suffix $-\sigma l \varsigma$ 'abnormal state' or 'disease'). Although not very often, this term has actually been used in clinical medicine, and usually means "pathological pigmentation". The name of this imaginary condition is a pun since its adjective comes from the French tissulaire, derived, in turn, from tissu 'tissue'. In Spanish, the latter word means three different things: 1) a fabric's texture, 2) any material made by weaving, and 3) "an aggregate of cells, usually of a particular kind, together with their intercellular substance that form one of the structural materials of a plant or an animal". The name of this disease therefore has a dual meaning: an abnormal pigmentation of the tissues (in the histopathological sense) and an abnormal pigmentation of any material made by weaving. The latter definition will be critical in the next paragraph.

Both nocturnal beehives and tissular chromosis have insomnia in common. All those suffering from tissular chromosis embroidered imaginarily the life of their ancestors in brightly colored wool. "The effort made by them to remember the most tedious details of the lives of people, whom they knew only in photographs, forced them to turn on the lamp to search on the bedside table, as if the gray wool, the brown wool (which was suitable for embroidering this or that passage of a biography), was there." This effort was preceded by a sharp pain in the stomach, which then left them bedridden.

"Estereognosia insomne" (insomniac stereognosis): In a later version of this short story, this disease was properly renamed "astereognosis insomne" (insomniac astereognosis) ${ }^{8}$. Although less overwhelming than the previous two, this condition is more uncomfortable. The patient does not recognize objects by touch. The latter symptom only occurs in complete darkness.

In clinical neurology, stereognosis is defined as the perception of shape and form of objects via tactile sense without the aid of sight. This word was coined by Heinrich Hoffmann (1819-1891) and it is derived from the Greek $\sigma \tau \varepsilon \rho \varepsilon o ́ \varsigma$, 'solid', and $\gamma l \gamma v \omega \sigma \sigma \kappa \omega$, 'to know'. The term astereognosis (or astereognosia) implies the absence or loss of this perception ${ }^{9,10}$. Tactile agnosia is another term for astereognosis ${ }^{11}$. The latter condition was first described by Friedrich August Benjamin Puchelt (1784-1856) ${ }^{9,10}$. One of the authors (B.E.) previously reported a case of tactile agnosia with a lesion restricted to the post-central gyrus ${ }^{12}$. 
"Copia Verborum" ("an abundance of words" in Latin): In a later version of this short story, this disease was renamed "labiagnosis" (gabgnosis?, glibgnosis?) ${ }^{8}$. While sometimes annoying, this episodic disorder was not unpleasant, and can occur at any time of day. It begins with a sharp pain in the central forehead and then the patient starts talking incessantly with an imponderable verbal fluency. During all this time, the pain continues. Such spells last about two hours.

The narrator of this short story caught this disease, and also fell in love with it, as did the other patients of Dr. Morgan. By means of this pathological gift-of-the-gab, the narrator won the heart of Dr. Morgan's fiancée. This charming doctor tried in vain to catch this disease, and then tried to treat the narrator... In the end, the doctor could not win his fiancée back.
For the observer, de Chirico's work is a strong stimulus to "awake dreams"13. Something similar can happen to Ocampo's readers. These imaginary neurological conditions allow her to explore improbable situations in everyday life, which could be interpreted as another manifestation of magic realism. She uses these diseases to invoke a series of enigmatic exempla, and what shall I love unless it be the Enigma?

\section{Acknowledgments}

We thank Drs. Joana Fernandes (USF Planície, Évora) and Samuel González García (British Embassy, Mexico City) for their generous support.

\section{References}

1. Cassirer E. The philosophy of symbolic forms. Vol.

3, The phenomenology of knowledge. New Haven:

Yale University Press; 1970.

2. Ocampo S, Weiss J. Silvina Ocampo. New York: NYRB; 2015.

3. Castellanos R.: Mujer que sabe latín... Mexico: SepSetentas; 1973. Silvina Ocampo y el "más acá”, p. 149-64.

4. Ocampo S. Poemas de amor desesperado. Buenos Aires: Sudamericana; 1949

5. Ocampo S. El médico encantador. Sur. 1960;(265):22-5.

6. Borges JL. Preface. In: Ocampo S, Oyeyemi H. Thus were their faces: stories. New York: NYRB; 2015.

7. Mackintosh FJ. Childhood in the works of Silvina Ocampo and Alejandra Pizarnik. Woodbridge:Tamesis; 2003.
8. Ocampo S. Las invitadas. 2nd ed. Buenos Aires: Orión; 1979.

9. Walusinski O. Pioneering the concepts of stereognosis and polyradiculoneuritis: Octave Landry (1826-1865). Eur Neurol. 2013;70(5-6):281-90.

10. Dercum FX. Studies in astereognosis. J Nerv Ment Dis. 1900;27(11):569-79.

11. Tonkonogy JM, Puente A. Localization of clinical syndromes in neuropsychology and neuroscience. New York: Springer; 2009.

12. Estañol B, Baizabal-Carvallo JF, Sentíes-Madrid H. A case of tactile agnosia with a lesion restricted to the post-central gyrus. Neurol India. 2008;56(4):471-3.

13. Bogousslavsky J. The last myth of Giorgio De Chirico: neurological art. Front Neurol Neurosci. 2010;27:29-45. 